\title{
COMMENT
}

\section{DISGRIMINATION BY MANAGERS AND SUPERVISORS: RECOGNIZING AGENT LIABILITY UNDER TITLE VII}

\author{
SCOTT B. GOLDBERG†
}

[T] he party whose voluntary conduct has caused the damage should suffer, rather than one who has had no share in producing it.

-Oliver Wendell Holmes ${ }^{1}$

\section{INTRODUCTION}

The principle of personal accountability is deeply rooted in the American legal tradition. ${ }^{2}$ Although liability of indirectly responsible parties is appropriate under certain circumstances, liability of the actual wrongdoer is generally a prerequisite, especially in the employment context. ${ }^{3}$ In the context of employment discrimination, however, several federal courts have held otherwise. ${ }^{4}$

Title VII of the Civil Rights Act of $1964^{5}$ (Title VII), enacted to combat employment discrimination and compensate its victims, ${ }^{6}$

† B.A. 1992, University of Michigan; J.D. Candidate 1995, University of Pennsylvania. I would like to thank Professor Susan Sturm, Ronald Barlin, Adam Cutler, Tom DeLeire, Michael Gilbert, Jaimy Levine, Darren Rosenblum, Leona Shaw, Hilary Siegel, and Judd Sneirson for their extensive substantive feedback. I am also grateful to Professor A. Leo Levin for inspiring me throughout law school, and to my family for their enduring encouragement.

1 Olver W. Holmes, The Common Law 84 (1881).

2 See, e.g., id. at 80-84 (discussing various tort liability theories, which "seem[] to be adopted by some of the greatest common-law authorities").

${ }^{3}$ Employers may be held liable for torts committed by their agents while acting within the scope of employment, see RESTATEMENT (SECOND) OF AGENCY $\$ 219$ (1958), but employer liability in no way supersedes the liability of the culpable agent. See id. $\S 343$.

1 See infra notes $15-16$ and accompanying text.

542 U.S.C. $\$ \S 2000$ e to 2000 e-17 (1988 \& Supp. V 1993).

${ }^{6}$ The United States Supreme Court has pronounced that the primary objectives of Title VII are eliminating discrimination from the workplace and compensating employment discrimination victims. See Albemarle Paper Co. v. Moody, 422 U.S. 405, 417-18 (1975) (describing Title VII's purposes of achieving equal employment opportunity, removing discriminatory employment barriers, and creating remedies to redress unlawful employment discrimination); see also Vakharia v. Swedish Covenant Hosp., 824 F. Supp. 769, 785 (N.D. Ill. 1993) ("Title VII always has served two 
prohibits racial and sexual harassment and discriminatory practices affecting hiring, firing, compensation, and benefits. ${ }^{7}$ Although Title VII explicitly permits victims of discrimination to seek both injunctive relief and damages, ${ }^{8}$ the statute fails to specify precisely whom victims may sue for such relief. ${ }^{9}$ Consequently, the federal judiciary has been required to make this determination.

In practice, federal courts readily hold liable employers ${ }^{10}$ who are proven to have violated Title VII. ${ }^{11}$ Unlawfully discriminatory acts, however, often emanate from agents of employers acting within the scope of their employment, such as when a chief executive officer of a major corporation makes a racially based hiring decision. ${ }^{12}$ In such cases, federal courts agree that employ-

purposes: to compensate the victims of discrimination . . . and to deter discrimination . . . . ); cf. Maria M. Carrillo, Hostile Environment Sexual Harassment by a Supervisor Under Title VII: Reassessment of Employer Liability in Light of the Civil Rights Act of 1991, 24 COLUM. HUM. RTS. L. REV. 41, 42 (1993) (identifying the objectives of the Civil Rights Act of 1991, Pub. L. No. 102-166, 105 Stat. 1071 (codified in scattered sections of 42 U.S.C.), as eliminating discrimination and compensating its victims).

${ }^{7}$ Title VII prohibits discrimination regarding "compensation, terms, conditions, or privileges of employment" on the basis of "race, color, religion, sex, or national origin." 42 U.S.C. \$ 2000e-2(a)(1); see also 2 IVAN E. BODENSTEINER \& ROSALIE B. LEVINSON, STATE \& LOCAL GOVERNMENT CIVIL. RIGHTS LIABILITY \$§ 5.09-.15 (1994) (discussing the types of discrimination Title VII prohibits).

${ }^{8}$ Remedies available under Title VII include compensatory and punitive damages. See 42 U.S.C. $\$ 1981 a(a)(1)$ (Supp. V 1993). If appropriate, equitable relief is also available in the form of back pay, reinstatement, or injunction. See 42 U.S.C. $\$ 2000 \mathrm{e}-$ $5(\mathrm{~g})$.

${ }_{9}$ Neither Title VII nor its amendments explicitly state which entities are subject to liability. See 42 U.S.C. $\$ \S 2000$ e to $2000 \mathrm{e}-17$ (1988 \& Supp. V 1993).

${ }^{10}$ This Comment uses the term "employer" in its ordinary sense to denote the corporation or entity employing the party against whom discrimination is directed. For Title VII's definition of "employer," see infra part I.A.

${ }^{11}$ See St. Mary's Honor Ctr. v. Hicks, 113 S. Ct. 2742, 2756 (1993) (holding that Title VII awards damages "against employers who are proven to have taken [discriminatory] employment action").

12 Title VII does not define the term "agent," see 42 U.S.C. $\$ \$ 2000$ e to $2000 \mathrm{e}-17$, and legislative history does not reveal its intended meaning. See Carrillo, supra note 6 , at 53. Federal courts have, nonetheless, been fairly consistent in defining who constitutes an agent within the meaning of the statute. See, e.g., Sauers v. Salt Lake County, I F.3d 1122, 1125 (10th Cir. 1993) (holding that an "individual qualifies as an "employer" under Title VII if he or she serves in a supervisory position and exercises significant control over the plaintiff's hiring, firing, or conditions of employment'" (quoting Paroline v. Unisys Corp., 879 F.2d 100, 104 (4th Cir. 1989))); Hamilton v. Rodgers, 791 F.2d 439, 443 (5th Cir. 1986) (defining "agent" as anyone who "participated in the decision-making process that forms the basis of the discrimination" (citations omitted)); York v. Tennessee Crushed Stone Ass'n, 684 F.2d 360, 362 (6th Cir. 1982) (dictum) (defining "agent" as an "employee to whom employment decisions have been delegated by the employer"). The crucial inquiry generally involves the level of authority an employee has over the conditions of employment 
ers may be held liable for the acts of their agents. ${ }^{13}$ Whether agents who actually discriminate may also be held liable, however, remains unresolved. ${ }^{14}$ This issue has sharply divided the federal courts of appeals ${ }^{15}$ and district courts, ${ }^{16}$ thus leaving the doctrines

of other employees. See, e.g., Sauers, 1 F.3d at 1125 (referring to the defendant supervisor as a "paradigm example" of an agent because the supervisor had ultimate authority over employment and working conditions); Hamilton, 791 F.2d at 442 (determining the agency of two superiors based on the authority they exerted over work assignments and staffing, as well as the fact that they filed a report that led to the plaintiff's suspension). Some courts seem to require that an agent be a supervisor or manager. See, e.g., Sauers, 1 F.3d at 1125 (implying that only supervisors are agents); Paroline v. Unisys Corp., 879 F.2d 100, 104 (4th Cir. 1989) (same).

${ }^{13}$ See Pommier v. James L. Edelstein Enters., 816 F. Supp. 476, 481 (N.D. Ill. 1993) (concluding that plaintiffs may generally secure "the full measure of available relief" under Title VII from employers for the actions of their agents); Barger v. Kansas, 630 F. Supp. 88, 92 (D. Kan. 1985) (noting that public employers can almost always be sued for the Title VII actions of their agents); see also Vakharia v. Swedish Covenant Hosp., 824 F. Supp. 769, 785-86 (N.D. Ill. 1993) (observing that employer liability is generally permissible under Title VII and that "personal accountability of supervisory employees is [necessary to achieve] Title V[II]'s broader goal of eradicating discrimination"). But see infra part II.A.I (discussing the unavailability of vicarious liability in certain cases of sexual harassment).

${ }^{14}$ As used throughout this Comment, "liability" is synonymous with "personal liability." Courts occasionally use confusing nomenclature that obscures distinctions between suing agents personally and suing agents in their official capacities. See, e.g., Harvey v. Blake, 913 F.2d 226, 228 (5th Cir. 1990) (holding that public officials may be liable "in [their] official capacities only" under Title VII). Suits against agents in their official capacities, however, are in fact suits against their employers. See Kentucky v. Graham, 473 U.S. 159, 165 (1985) ("Official capacity suits . . . 'generally represent only another way of pleading an action against an entity of which an officer is an agent." (citations omitted)); Monell v. Department of Social Servs., 436 U.S. 658, 690 n.55 (1978) (same, in the context of 42 U.S.C. $\$ 1983$ ); see also Sauers, 1 F.3d at 1125 (applying Graham in the Title VII context); Busby v. City of Orlando, 931 F.2d 764, 776 (11th Cir. 1991) (same); Stafford v. Missouri, 835 F. Supp. 1136, 1149 (W.D: Mo. 1993) (citing Graham); cf. Coffin v. South Carolina Dep't of Social Servs., 562 F. Supp. 579, 586-87 (D.S.C. 1983) (applying Monell in the context of age discrimination).

${ }^{15}$ The Fourth and Sixth Circuits have determined that Title VII permits agent liability, see Paroline, 879 F.2d at 104; Jones v. Continental Corp., 789 F.2d 1225, 1231 (6th Cir. 1986), but the Ninth, Tenth, and Eleventh Circuits have reached the opposite conclusion. See Sauers, 1 F.3d at 1125; Miller v. Maxwell's Int'l, Inc., 991 F.2d 583, 588 (9th Cir. 1993), cert. denied, 114 S. Ct. 1049 (1994); Busby, 931 F.2d at 772.

Although the Fifth Circuit has considered the issue of agent liability, inconsistent rulings cast doubt on its current position. Compare Hamilton, 791 F.2d at 442-43 (holding two agents liable for Title VII violations after specifically addressing the permissibility of doing so) with Harvey, 913 F.2d at 227-28 (holding that agents may not be held liable under Title VII) and Clanton v. Orleans Parish Sch. Bd., 649 F.2d 1084, 1099 \& n.19 (5th Cir. Unit A July 1981) (holding that public officials cannot be liable for back pay under Title VII). Harvey is the more recent decision, but the Fifth Circuit's continued adherence to a self-imposed rule "that no panel of this circuit can overrule a decision previously made by another [panel]" implies that Hamilton 
defining Title VII liability in a state of disarray. ${ }^{17}$

This Comment analyzes the issue of agent liability under Title VII and concludes that managers and supervisors who unlawfully discriminate should be held personally accountable to their victims. ${ }^{18}$ Part I demonstrates that the plain language of Title VII provides a basis for agent liability. Part II examines the legislative intent underlying Title VII and determines that agent liability comports with Title VII's statutory objectives. Part III evaluates the public policy implications of holding agents liable under Title VII and concludes that recognizing agent liability under Title VII is desirable.

remains good law. Harvey, 913 F.2d at 228 n.2 (citing Ryals v. Estelle, 661 F.2d 904, 906 (5th Cir. Nov. 1981)). In Harvey, the Fifth Circuit attempted to reconcile these inconsistent rulings by stating that the Hamilton court made no distinction between the agent's official and unofficial capacity. See id. The Harvey court's reasoning is unpersuasive, however, because the Hamilton court explicitly held that agents may be found personally liable. See Hamilton, 791 F.2d at 443 ("To hold otherwise would encourage [agents] to believe that they may violate Title VII with impunity." (emphasis added)).

${ }^{16}$ District courts within the Second and Seventh Circuits continue to reach opposite conclusions regarding agent liability, apparently refusing to follow their respective courts of appeals, which have upheld agent liability without explicitly addressing the issue. See Zaken v. Boerer, 964 F.2d 1319, 1322-24 (2d Cir.) (upholding liability of an agent owning 98\% of employer company), cert. denied, 113 S. Ct. 467 (1992); Gaddy v. Abex Corp., 884 F.2d 312, 318-19 (7th Cir. 1989) (same). Compare, e.g., Bridges v. Eastman Kodak Co., 800 F. Supp. 1172, 1180 (S.D.N.Y. 1992) (recognizing agent liability) with Friend v. Union Dime Sav. Bank, 24 Fair Empl. Prac. Cas. (BNA) 1307, 1310 (S.D.N.Y. 1980) (dictum) (rejecting agent liability); compare also Vakharia, 824 F. Supp. at 784 (recognizing agent liability) with Pelech v. Klaff-Joss, LP, 828 F. Supp. 525, 529 (N.D. Ill. 1993) (rejecting agent liability) and Weiss v. CocaCola Bottling Co., 772 F. Supp. 407, 411 (N.D. Ill. 1991) (same).

Inconsistency abounds among district courts in the remaining circuits. See Henry v. E.G. \& G. Mo. Metals Shaping Co., 837 F. Supp. 312, 314 (E.D. Mo. 1993) (declining to recognize agent liability because of lack of "clear direction" from "sister courts or the appellate court"). Compare, e.g., Lamirande v. Resolution Trust Corp., 834 F. Supp. 526, 529 (D.N.H. 1993) (recognizing agent liability) with Stafford, 835 F. Supp. at 1149 (rejecting agent liability).

${ }^{17}$ On this very issue of agent liability under Title VII, the United States Supreme Court has twice recently denied certiorari, first to the United States Court of Appeals for the Ninth Circuit, see Miller v. La Rosa, 114 S. Ct. 1049 (1994), and second to the United States Court of Appeals for the Fifth Circuit, see Grant v. Lone Star Co., 115 S. Ct. 574 (1994).

${ }^{18}$ This Comment focuses solely on disparate treatment violations. Whether the analysis employed herein might prove useful for determining agent liability in the disparate impact context is therefore beyond the scope of this Comment. 


\section{Statutory Language Provides a Basis for AGENT LIABILITY UNDER TITLE VII}

According to the United States Supreme Court's longstanding pronouncement on statutory construction, "the meaning of a statute must, in the first instance, be sought in the language in which the act is framed." ${ }^{19}$ As the following sections demonstrate, federal courts have disagreed on the meaning of Title VII's language. A literal reading of Title VII supports agent liability, although some courts have used more indirect readings of the statute to reach the opposite conclusion. The reasoning of these courts is flawed, however, and therefore the literal reading of the statute should prevail.

\section{A. A Literal Reading of Title VII Supports Agent Liability}

Title VII does not state explicitly who may be held liable for violating its prohibitions. ${ }^{20}$ Federal courts implicitly recognize that the statutory provisions defining unlawful employment practices most directly indicate which discriminators fall within the ambit of statutory liability. ${ }^{21}$ Such provisions delineate the conduct that constitutes "an unlawful employment practice for an employer."22 Accordingly, exposure to liability turns upon who is "an employer" within the meaning of the statute, which is defined as "a person engaged in an industry affecting commerce who has fifteen or more employees ... and any agent of such person." 23 Thus, simply substituting the statutory definition of employer into the provisions defining unlawful employment practices plainly establishes a basis for agent liability. ${ }^{24}$

${ }^{19}$ Caminetti v. United States, 242 U.S. 470, 485 (1917); see also 2A NORMAN J. SiNGER, STATUTES AND STATUTORY CONSTRUCTION \$ 46.01 (5th ed. 1992) (discussing the importance of statutory language to the process of statutory construction).

${ }^{20}$ See supra note 9.

${ }^{2 l}$ See infra note 24 and accompanying text.

2242 U.S.C. $\$ 2000 \mathrm{e}-2$ (a) (emphasis added).

${ }^{23} 42$ U.S.C. $\$ 2000 \mathrm{e}$ (b) (emphasis added).

${ }^{24}$ Many courts permit agent liability solely on this basis. See, e.g., Goodman v. Board of Trustees of Community College Dist. 524, 498 F. Supp. 1329, 1332 (N.D. Ill. 1980) (allowing agent liability based on the language of Title VII); $c f$. House v. Cannon Mills Co., 713 F. Supp. 159, 161-62 (M.D.N.C. 1988) (using the same approach in the context of the Age Discrimination in Employment Act).

Quite surprisingly, some courts have interpreted $\S 2000 \mathrm{e}-2$ as prohibiting agent liability. See, e.g., Padway v. Palches, 665 F.2d 965, 968 (9th Cir. 1982) (concluding 


\section{B. Alternate Readings of Title VIr's Language Are Flawed}

The United States Court of Appeals for the Ninth Circuit recently espoused the various rationales of those federal courts rejecting a literal reading of Title VII. ${ }^{25}$ As the following sections demonstrate, each of these rationales is logically flawed and therefore fails to provide a persuasive reason for denying agent liability.

\section{Title VII's Definition of "Employer" Does Not Provide a Persuasive Reason for Rejecting Agent Liability}

\section{a. Interpreting Title VII's Inclusion of "Agents"}

The explicit inclusion of agents within Title VII's definition of "employer" suggests, by simple substitution, that agents may be held liable for their unlawfully discriminatory conduct. ${ }^{26}$ Some federal courts, most notably the Ninth Circuit, have nonetheless used the identical provision to reach the opposite conclusion. Employing a representative approach, the Ninth Circuit concluded that the "obvious purpose of [including "agent" in the definition of employer] was to incorporate respondeat superior liability into the statute," not to provide a basis for agent liability. ${ }^{27}$

This approach to resolving the issue of agent liability under Title

that Title VII addresses conduct of employers and not of agents) (citing Clanton v. Orleans Parish Sch. Bd., 649 F.2d 1084, 1099 (5th Cir. Unit A July 1981)). It is difficult to reconstruct the reasoning behind these decisions, unless perhaps these courts ignored or overlooked the statutory definition of "employer." Courts subsequently considering such cases have rejected the reasoning of those courts that have prohibited agent liability. See, e.g., Barger v. Kansas, 630 F. Supp. 88, 91 (D. Kan. 1985) (describing the court's reasoning in Padway as "clearly erroneous"); see also Miller v. Maxwell's Int'l, Inc., 991 F.2d 583, 587 (9th Cir. 1993) (conceding that readings of Title VII that permit agent liability would not be "without merit," but rejecting agent liability nonetheless), cert. denied, 114 S. Ct. 1049 (1994).

${ }^{25}$ See Miller, 991 F.2d at 587-88. The Fifth Circuit referentially adopted these rationales by accepting the reasoning of Miller in Grant v. Lone Star Co., 21 F.3d 649, 652-53 (5th Cir.) (declining to impose agent liability), cert. denied, 115 S. Ct. 574 (1994).

${ }^{26}$ See supra part I.A (finding support for agent liability in the plain language of 42 U.S.C. $§ 2000 \mathrm{e})$.

${ }^{27}$ Miller, 991 F.2d at 587 (quoting the unpublished opinion of the district court below). The doctrine of respondeat superior liability, a form of vicarious liability, permits employers to be held strictly liable for the torts of their agents under certain circumstances. See W. PAGe Keeton et al., Prosser and KeEton on the LAW OF TORTS $\$ 69$ (5th ed. 1984); W. EDWARD SELL, AGENCY \$\$ 95-96; see also RESTATEMENT (SECOND) OF AGENCY, supra note $3, \S 219$ (discussing the circumstances under which employers may be held liable for the torts of their employees). 
VII is unpersuasive for two reasons. First, the Ninth Circuit cited no authority to support its assertion other than the unpublished opinion of the district court below. ${ }^{28}$ Second, even assuming that Congress included the word "agent" for respondeat superior purposes, it does not necessarily follow that Congress intended suits against employers to constitute the exclusive means of Title VII liability. ${ }^{29}$ Such a conclusion is especially dubious given that a literal reading of the statute dictates a contrary outcome and thus does not weigh in favor of denying agent liability under Title VII. ${ }^{30}$

\section{b. Interpreting Title VII's Exclusion of Employers with Fewer Than Fïfeen Employees}

The Ninth Circuit's second rationale for rejecting agent liability focuses on Title VII's coverage of only those employers with fifteen or more employees. ${ }^{31}$ After assuming that Congress would intend to treat individuals and small entities similarly, the court concluded that, given the statute's protection of small businesses, it would be "inconceivable that Congress intended to allow civil liability to run against [agents]. ${ }^{32}$

The logical error of this analysis lies in its improper assessment of the reasons Congress limited Title VII's coverage to larger employers. As some federal courts have recognized, legislative history reveals that Congress excluded small employers from Title VII's coverage to preserve the autonomy of family-run businesses that prefer to hire friends and family members. ${ }^{33}$ This rationale,

${ }^{28}$ See Miller, 991 F.2d at 587. The district court opinion cannot be accessed by electronic database.

${ }^{29}$ Given that Congress never addressed the issue of agent liability, see infra note 43 , it seems especially tenuous for the court to have eliminated one of two equally plausible-and mutually compatible-constructions of the statute's inclusion of agents without invoking significant supporting authority.

${ }^{30}$ See Nixon v. United States, 113 S. Ct. 732, 737 (1993) (recognizing the "well established rule that the plain language of the enacted text is the best indicator of intent"); supra part I.A (finding a basis for agent liability in Title VII's plain language).

${ }^{31}$ See Miller, 991 F.2d at 587; see also 42 U.S.C. $\$ 2000$ e(b) (stating that businesses with fewer than 15 employees are not covered under Title VII's prohibitions); supra text accompanying note 23.

${ }^{32}$ Miller, 991 F.2d at 587.

${ }^{39}$ See Lamirande v. Resolution Trust Corp., 834 F. Supp. 526, 528 (D.N.H. 1993) (explaining the 15-employee limitation as a device used "to protect small family-run businesses from discriminatory hiring claims based on their preference for hiring friends and relatives" (citing Armbruster v. Quinn, 711 F.2d 1332, 1337 n.4 (6th Cir. 1983) and legislative history)). The court specifically relied on the congressional debates over the 1972 amendments to Title VII, particularly the remarks of Senator 
however, does not apply to individual agents. Congress's intent to preserve a sphere of autonomy for small businesses does not suggest that Congress would similarly protect individual discriminators, especially when these individuals are agents of em-ployers covered by Title VII. Rather, agents of covered employers are acutely involved in the business decisions Congress intended Title VII to reach. ${ }^{34}$ Contrary to the Ninth Circuit's reasoning, then, Congress would not have intended violators within covered enterprises to escape the consequences of their actions.

\section{Title VII's Damage Limitation Provisions Do Not Provide a Legitimate Reason for Rejecting Agent Liability}

The Ninth Circuit also based its denial of agent liability on the language of the Civil Rights Act of 1991, which both authorized compensatory and punitive damages and limited the size of such awards according to the number of people employed by the liable defendant. ${ }^{35}$ After correctly noting that no provision explicitly limits damage awards against individuals, ${ }^{36}$ the court concluded that Congress never envisioned agent liability under Title VII. ${ }^{37}$ This interpretation's appeal lies in its ability to prevent the potentially unjust result of imposing even greater liability on an

Fannin, see 118 CoNG. REC. 2409-10 (1972), and Senator Ervin, see id. at 3171 (1972). See Lamirande, 834 F. Supp. at 528.

${ }^{34}$ See supra note 12 (noting the importance of decision-making authority as a factor in judicial interpretation of the term "agent").

${ }^{35}$ See 42 U.S.C. \$ 1981a(a)(1) (Supp. V 1993) (authorizing compensatory and punitive damage awards, but only in cases of "unlawful intentional discrimination," as opposed to disparate impact cases). The damage limitation provisions stipulate:

The sum of the amount of compensatory damages awarded under this section ... . and the amount of punitive damages awarded under this section, shall not exceed, for each complaining party-

(A) in the case of a respondent who has more than 14 and fewer than 101 employees ..., \$50,000;

(B) in the case of a respondent who has more than 100 and fewer than 201 employees ... , \$100,000;

(C) in the case of a respondent who has more than 200 and fewer than 501 employees ..., $\$ 200,000$;

(D) in the case of a respondent who has more than 500 employees . . , $\$ 300,000$.

Id. $\$ 1981 \mathrm{a}(\mathrm{b})(3)$.

${ }_{36}$ The damage limitation provisions apply only to defendants with "more than 14 ... employees." Id.

${ }^{37}$ See Miller, $991 \mathrm{~F} .2 \mathrm{~d}$ at 587-88 $\mathrm{n.2}$ (concluding that if Congress intended to permit agent liability, it would have created a damage category encompassing respondents without employees, that is, a category covering individual agents). 
agent than on the employer, who often would have greater financial resources than the individual agents it employs. ${ }^{38}$

Title VII's silence regarding the range of damages available against this class of potential defendants does not, however, indicate that Congress intended to foreclose agent liability. The damage limitation provisions are also silent with respect to other Title VII defendants whose exposure to liability remains uncontroversial. In particular, the damage limitation provisions do not expressly cover employment agencies and labor organizations having under fifteen employees, despite Title VII's undisputed coverage of such entities regardless of their size. ${ }^{39}$ It would seem disingenuous to argue that Congress intended its silence on damage limitations regarding these potential defendants to nullify the content of statutory provisions specifically directed at them. Similarly, legislative silence does not indicate that Congress intended to leave agents outside Title VII's reach. ${ }^{40}$ Because all alternative readings of Title VII's language prove unpersuasive, ${ }^{41}$ the literal reading, which supports

${ }^{38}$ The courts, however, are fully capable of preventing unjust results. In one case involving a suit under the Americans with Disabilities Act, 42 U.S.C. $\S \S 12,101-12,213$ (Supp. V 1993), a district court read \$ 1981a as limiting the damages for which the agent could be liable to the extent of the employer's damage exposure. See EEOC v. AIC Sec. Investigations, Ltd., 823 F. Supp. 571,577 (N.D. Ill. 1993) (rejecting the "purely mechanical" argument that $\$ 1981$ a imposes no limitation on damages against agents because agents lack the requisite number of employees).

${ }^{39}$ See 42 U.S.C $\$ 2000$ e(c)-(d) (defining the terms "employment agency" and "labor organization"). Title VII defines unlawful employment practices for employment agencies and labor organizations at 42 U.S.C. $\$ \S 2000 \mathrm{e}-2(\mathrm{~b})$ to $2000 \mathrm{e}-2$ (d) and $\S \S 2000 \mathrm{e}-3$ (a) to $2000 \mathrm{e}-3(\mathrm{~b})$.

${ }^{40}$ Even if agents constituted the only class having less than 15 employees to which Title VII potentially applies, commonly accepted principles of statutory construction nonetheless would undermine the Ninth Circuit's interpretation of the damage limitation provisions. Under such a scenario, the words "more than 14 . . employees" would be superfluous if damages were not available against individuals, because employers with less than 15 employees fall outside Title VII's coverage. 42 U.S.C. $\S 1981 \mathrm{a}(\mathrm{b})(3)(\mathrm{A})$ (Supp. V 1993). Such an interpretation should therefore be rejected, because statutory interpretation should give meaning to all the words in any given piece of legislation. See Marek v. Chesny, 473 U.S. 1, 9 (1985) (recognizing the preference for statutory interpretations which give meaning to all words); 2A SINGER, supra note $19, \S 46.06$ (discussing the pervasiveness of the rule that statutes should be read to avoid rendering portions superfluous).

41 The Ninth Circuit advanced a third, but equally flawed, rationale for rejecting agent liability. Relying on its 1982 opinion in Padway v. Palches, 665 F.2d 965, 968 (9th Cir. 1982), the Ninth Circuit concluded that Title VII's original remedies of back pay, reinstatement, and injunctive relief apply to employers but not to individuals. See Miller, 991 F.2d at 587. Similarly, the court extrapolated, the statute does not impose liability on agents. See id. (citing Padway, 665 F.2d at 968).

Since the Padway decision, however, Congress has changed Title VII's remedial 
agent liability under Title VII, remains the most compelling. ${ }^{42}$

\section{Agent Liability FuRTHERS THE CONGRESSIONAL OBJECTIVES OF TITLE VII}

Because Title VII's language does not unambiguously resolve the issue of agent liability, one must look to the statute's legislative history for further guidance. ${ }^{43}$ Although Congress never specifically addressed the issue of agent liability, ${ }^{44}$ Title VII's broad objectives are clear: to eradicate employment discrimination and to provide redress for the victims of such discrimination. ${ }^{45}$ The following sections consider whether agent liability serves these dual

scheme to authorize compensatory and punitive damages in cases of intentional discrimination. See Civil Rights Act of 1991, Pub. L. No. 102-166, § 1977A, 105 Stat. 1071, 1072 (codified at 42 U.S.C. $\$ 1981 a(a)(1)$ (Supp. V 1993)). The statutory amendment has called into question the extent to which courts should rely on pre1991 decisions as authority for current Title VII analyses of agent liability. Compare Bridges v. Eastman Kodak Co., 800 F. Supp. 1172, 1180 (S.D.N.Y. 1992) (rejecting pre-1991 Title VII decisions as authority on the issue of agent liability) with Miller, 991 F.2d at 587 \& $\mathrm{n} .2$ (citing Padway's pre-1991 interpretation of Title VII as authority on the issue of agent liability).

Although subsequent changes to remedial provisions do not necessarily alter the coverage of the statute, see Textile Workers Union v. Lincoln Mills, 353 U.S. 448, 461 (1957) (Frankfurter, J., dissenting) (criticizing majority for using a remedial provision of an amendment to expand a statute's coverage), the reasoning of pre-1991 decisions should nonetheless be rejected for their faulty logic. These decisions, which reject agent liability on the assumption that equitable relief applies only to employers, see Padway, 665 F.2d at 968, fail to recognize that injunctive orders can be directed appropriately at agents. See, e.g., Robinson v. Jacksonville Shipyards, Inc, 760 F. Supp. 1486, 1534 (M.D. Fla. 1991) (limiting injunctive relief to a corporate employer because the court expected two agents of the employer to comply, and because the court wished to avoid the inconvenience of releasing the agents from the order when their employment with the corporation eventually terminated).

${ }^{42}$ See supra part I.A (discussing the plain meaning of the unlawful employer practice provisions of the statute).

${ }^{13}$ See INS v. Cardoza-Fonseca, 480 U.S. 421, 432 n.12 (1987) (discussing the role of legislative history in deciphering legislative intent); see also 2A SINGER, supra note $19, \S 45.05$ (noting a virtual consensus among scholars and judges that courts should interpret statutes in light of legislative intent).

${ }_{11}$ See Charles S. Mishkind \& Louise B. Wright, Joinder of Individual Defendants in Employment Litigation: Is Removal Still Possible?, 19 EMPLOYEE REL. L.J. 117, 126 (1993) (noting that Title VII's legislative history is "silent" on point of agent liability).

45 Commonly accepted principles of statutory interpretation dictate that, for issues not expressly considered by Congress, the legislature's general purposes in enacting the statute provide the best indication of legislative intent. See 2A SINGER, supra note $19, \S 45.09$ (suggesting that "[1]egislative purpose may . . . be a valuable guide to decision" for situations unforeseen by the legislature and for situations not unambiguously resolved by statutory language); see also supra note 6 (discussing Title VII's objectives). 
purposes, concluding in the affirmative.

\section{A. Agent Liability Helps Victims Secure Compensation}

Absent agent liability, victims of discrimination must resort to suing the wrongdoer's employer alone. The following subsections explain why employer liability is often insufficient to ensure compensation for victims of unlawful discrimination, particularly in the contexts of agents engaging in hostile environment sexual harassment, judgment-proof employers, and litigation-shy victims. In these situations, suing agents may provide victims realistic opportunities for compensation, especially when agents are highranking company executives with significant wealth.

\section{Agent Liability Is Needed in Cases of Hostile Environment Sexual Harassment}

Although courts routinely hold employers vicariously liable for most Title VII violations committed by their agents, ${ }^{46}$ vicarious liability often does not extend to the disturbingly common Title VII violation of hostile environment sexual harassment, ${ }^{47}$ first recognized by the United States Supreme Court in Meritor Savings Bank v. Vinson. ${ }^{48}$ In Meritor, the Court specifically refused to approve a strict rule of vicarious liability for employers. ${ }^{49}$ The Court instead held that common-law agency principles "place some limits on the acts of [agents] for which employers under Title VII are to be held responsible." ${ }^{\text {A }}$ A determination of employer liability consequently

${ }^{16}$ See Carrillo, supra note 6, at 75 (stating that hostile environment sexual harassment is the only type of Title VII violation for which employers are not always held vicariously liable).

${ }^{17}$ Surveys conducted in recent years suggest that sexual harassment occurs with alarming frequency. See Alba CONTE, SEXUAL HARASSMENT IN THE WORKPLACE: LAW AND PRACTICE $§ 1.1(1990)$ (summarizing the results of various surveys measuring the frequency of sexual harassment).

${ }^{18} 477$ U.S. 57, 71 (1986). The Supreme Court recognized both hostile environment sexual harassment and quid pro quo sexual harassment as Title VII violations in Meritor. See id. at 65-67, 73. Hostile environment sexual harassment refers to the creation of unpleasant or offensive working conditions for an employee based on the employee's gender. See id. at 64-67 (defining hostile environment sexual harassment); see also MACK A. PLAYER, EMPLOYMENT DISCRIMINATION LAW 249-55 (practitioner's ed. 1988) (discussing generally both quid pro quo and hostile environment sexual harassment).

${ }^{49}$ See Merilor, 477 U.S. at 72.

${ }^{50} \mathrm{Id}$. This result falls short of implying that no Title VII violation has occurred, however, because employer notice of unlawful conduct exposes the employer to 
depends upon "the circumstances of a particular case."51

The Meritor Court specifically directed lower courts to commonlaw agency principles found in the Restatement (Second) of Agency, ${ }^{52}$ which provides that employers are "not subject to liability for the torts of [agents] acting outside the scope of their employment. ${ }^{n 53}$ Although lower courts have inconsistently identified the conditions giving rise to vicarious liability, ${ }^{54}$ employers certainly are not always vicariously liable for sexual harassment by their agents. ${ }^{55}$ Agent liability, therefore, furthers the congressional goal of compensating the victims of discrimination by providing a defendant against whom a plaintiff realistically can prevail in cases in which doctrinal gaps foreclose recovery against employers.

liability for the identical conduct. See id. at 71-72.

${ }^{51}$ Id. at 73; see also William L. Kandel, Financial Exposure of Managers for Personnel Decisions, 19 EMPLOYEE REL. L.J. 267, 272 (1993) (noting the Supreme Court's rejection of strict employer liability for unlawful discriminatory acts of their agents). But see Carrillo, supra note 6, at 76 (arguing Meritor implies that agents act outside the scope of their employment authority when creating a sexually hostile environment, thereby exempting the employer from liability under common-law agency principles).

52 See Merilor, 477 U.S. at 72.

${ }^{33}$ RESTATEMENT (SECOND) OF AGENCY, supra note 3, § 219(2) (emphasis added). This general rule admits four exceptions: (1) the employer intended the conduct or the consequences; (2) the employer was negligent or reckless; (3) the conduct violated a nondelegable duty of the employer; and (4) the agent purported to act or speak on behalf of the principal, and there was reliance upon apparent authority, or the agent was aided in accomplishing the tort by the existence of the agency relationship. See id.

${ }^{54}$ See Carrillo, supra note 6, at 71-74 (discussing the various ways lower courts have interpreted Meritor); see also Brian P. Conway, Comment, $A$ View Against Strict Employer Liability Under Title VII for Sexually Offensive Work Environments Created by Supervisory Personnel: Meritor Savings Bank v. Vinson, 91 DiCK. L. REV. 1157, 1175 (1987) (stating that Meritor left the issue of vicarious liability "in a state of turmoil").

${ }^{55}$ See Meritor, 477 U.S. at $72-73$ (holding that employers are not strictly liable for all Title VII violations of their agents); Carrillo, supra note 6, at 57 (arguing that employers generally are not vicariously liable for hostile environment sexual harassment); see also Kandel, supra note 51, at 272 (discussing the liability "gap" created by Meritor). But see Levendos v. Stern Entertainment, Inc., 909 F.2d 747, $751-52$ (3d Cir. 1990) (imputing to the employer acts of supervisory employees who had the power to hire, fire, and promote); Volk v. Coler, 845 F.2d 1422, 1436 (7th Cir. 1988) (holding employer strictly liable for sexual harassment by supervisory employees who had the power to hire, fire, or promote).

Even those Justices in favor of more expansive employer liability for hostile environment sexual harassment would decline to impose employer liability when, unbeknownst to the employer, agents sexually harass victims who are not their direct subordinates. See Meritor, 477 U.S. at 77 (Marshall, J., joined by Brennan, Blackmun, and Stevens, J., concurring in the judgment). 


\section{Agent Liability Is Needed When Employers Are Judgment-Proof}

Even when employers are susceptible to vicarious liability under Title VII, suing them is monetarily fruitless if they lack sufficient funds to satisfy adverse judgments. In cases of bankrupt employers, for example, agent liability provides the only means for potential recovery. ${ }^{56}$ Similarly, agent liability aids full recovery when employers are capable of only partial satisfaction of adverse judgments. In both situations, agent liability helps realize the congressional goal of full compensation for unlawful discrimination by giving victims the option of suing an additional defendant who may be solvent. ${ }^{57}$

\section{Agent Liability Is Needed to Encourage Litigation-Shy Victims to Sue}

In addition to doctrinal gaps and practical difficulties that may impede victims of employment discrimination from recovering full judgments, nonmonetary factors may discourage victims from suing employers. Most notably, victims of discrimination may fear the social repercussions that often accompany suits against employers. A Title VII lawsuit might anger the supervisors and managers who may greatly influence the victim's career-advancement opportunities, as well as offend the victim's fellow employees. ${ }^{58}$ Although suits against agents might also exacerbate negative sentiments among a victim's colleagues, agent liability may partially alleviate this concern by providing victims a choice of defendants. ${ }^{59}$ If the

${ }^{56}$ See, e.g., EEOC v. Vucitech, 842 F.2d 936, 944-46 (7th Cir. 1988) (considering whether to hold successor corporation liable for bankrupt predecessor's obligations); see also Vakharia v. Swedish Covenant Hosp., 824 F. Supp. 769, 786 (N.D. Ill. 1993) (recognizing that employment discrimination plaintiffs are sometimes unable to sue because their employers are bankrupt).

${ }^{57}$ The need for agent liability in cases of judgment-proof employers is so compelling that one court, after rejecting agent liability, suggested it would reconsider the issue if the employer were shown to be "undercapitalized." See Archer v. Globe Motorists Supply Co., 833 F. Supp. 211, 214 (S.D.N.Y. 1993) (recognizing a need to pierce the corporate veil to ensure recovery for a Title VII plaintiff where an undercapitalized employer is incapable of satisfying an adverse judgment).

${ }^{58}$ Even if the discrimination ends or prevents an employment relationship involving the victim, potential plaintiffs still have these concerns if they seek reinstatement, see supra note 8 , if they have developed friendships that may be jeopardized, or if they anticipate business dealings with the employer or its agents in the future. Title VII mitigates this concern to some degree by prohibiting retaliatory discharge. See 42 U.S.C. $\S 2000 \mathrm{e}-3$ (a).

${ }^{59}$ Even if agents implead employers, presumably plaintiffs would not incur as 
agent is unpopular, for example, the victim might choose to sue the agent exclusively, foregoing a suit against the employer. ${ }^{60}$

Suing the agent instead of the employer may also encourage victims to sue because it would not jeopardize the ability of the employer to stay in business and continue to supply jobs. ${ }^{61}$ Additionally, agent liability provides victims of unlawful discrimination an opportunity to sue as a means of allocating blame. In this way, agent liability offers victims an added incentive to file suit when they perceive agents as more responsible than their employers for injury. ${ }^{62}$ Therefore, by encouraging victims of unlawful discrimination to sue in a variety of situations, agent liability furthers the congressional goal of redressing employment discrimination. ${ }^{63}$

\section{B. Agent Liability Probably Deters Employment Discrimination}

Although agent liability certainly furthers Title VII's goal of compensating victims of employment discrimination, ${ }^{64}$ it is somewhat unclear how agent liability comports with the other statutory objective of deterrence. ${ }^{65}$ Under a regime of agent liability, Title VII deters agents ${ }^{66}$ in two ways: agents fear direct exposure to

many social repercussions as if they were to sue employers directly.

${ }^{60}$ Congress's goal is to compensate victims in fact, not merely to provide an opportunity for compensation that may be undesirable to victims. Cf. supra note 6 and accompanying text (discussing the congressional goal of compensation).

${ }^{61}$ Suing agents is not likely to affect the financial stability of the employer. Even when employers show a willingness to indemnify or insure agents, courts may hesitate to permit such arrangements. Cf. Kyriazi v. Western Elec. Co., 476 F. Supp. 335, 341 (D.N.J. 1979) (forbidding an employer from compensating its agent for tort liability incurred as a result of sexually harassing an employee, because such indemnification would defeat the purpose of the court's discretionary award of punitive damages).

${ }^{62}$ Agent liability also provides additional monetary incentives to sue. Although the compensatory damage award always remains constant, see RESTATEMENT (SECOND) OF TORTS $\S 902$ (1979), the total punitive damage award increases as the number of liable defendants increases. See id. $\$ 908 \mathrm{c} \mathrm{cmts.} \mathrm{(explaining} \mathrm{that} \mathrm{punitive} \mathrm{damages}$ are determined by the amount needed to punish and deter each defendant found liable); infra notes 76-77 and accompanying text.

${ }^{69}$ Encouraging victims to sue also furthers the objective of eliminating employment discrimination by deterring future discrimination. See infra part II.B (discussing the deterrent effect of agent liability).

${ }^{64}$ See supra part II.A.

${ }^{65}$ Compare Hamilton v. Rodgers, 791 F.2d 439, 443 (5th Cir. 1986) ( ${ }^{4}[$ Not t]o hold [agents liable] would encourage [them] to believe that they may violate Title VII with impunity.") with Miller v. Maxwell's Int'l, Inc., 991 F.2d 583, 588 (9th Cir. 1993) ("An employer that has incurred civil damages because one of its [agents] believes he [or she] can violate Title VII with impunity will quickly correct that [agent]'s erroneous belief."), cert. denied, 114 S. Ct. 1049 (1994).

${ }^{66}$ Agent liability does not alter the liability scheme for cases in which employers 
liability, and they fear employer repercussions due to the employer's exposure to vicarious liability. ${ }^{67}$ Absent agent liability, Title VII deters agents only indirectly through the threat of employer repercussions. This observation, however, does not necessarily mean that agent liability increases overall deterrence. Because agents partially satisfy damage awards, employers expecting to incur less vicarious liability might choose to deter their agents with less vigor. Unfortunately, a lack of empirical data prevents a quantitative comparison of agent liability's competing effects on deterrence. In this light, the following subsections suggest why, nonetheless, agent liability probably increases overall deterrence to agents. ${ }^{68}$

\section{Common Sense Suggests That Agent Liability Increases Overall Deterrence}

Agent liability entails the threat of personal bankruptcy to agents who discriminate, and commentators have recognized this threat to be quite potent. ${ }^{69}$ In addition to being perhaps the strongest potential deterrent under Title VII, the fear of personal bankruptcy exists in situations in which threats of employer repercussions are insufficient. Once their pensions vest, for example, company managers or supervisors on the brink of retirement are not deterred effectively by possible discharge, lower compensation, or curtailment of advancement opportunities. ${ }^{70}$ In situations like these, direct exposure to liability may represent the only effective way to deter discrimination by agents.

themselves discriminate, because liability runs directly against the employer in these cases. See supra note 11 and accompanying text.

${ }^{67}$ Employer repercussions for discrimination might include, for example, discharge, decreased compensation, or curtailment of advancement opportunities. See Alan O. Sykes, The Boundaries of Vicarious Liability: An Economic Analysis of the Scope of Employment Rule and Related Legal Doctrines, 101 HARV. L. REV. 563, 569-70 (1988) (identifying general techniques employers use to avoid exposure to vicarious liability); see also Kauffman v. Allied Signal, Inc., 970 F.2d 178, 185 (6th Cir. 1992) (discussing the employer's policy of immediately discharging agents who violate Title VII).

${ }^{69}$ Emotional and social deterrents to agents presumably exist in equal force regardless of Title VII's liability scheme because agents are judged violators of Title VII without regard to whether liability runs against them. Accordingly, the analysis of this subsection focuses on financial deterrence. Criminal penalties are not a potential deterrent, because Title VII provides only civil remedies. See 42 U.S.C. $\S 2000 \mathrm{e}-5$.

${ }^{69}$ See, e.g., Sykes, supra note 67 , at $567 \mathrm{n} .9$ (maintaining that potential bankruptcy is a powerful deterrent to agents under Title VII).

${ }^{70}$ See supra note 67 (discussing sanctions an employer might impose for employee misconduct). 
Furthermore, employers are likely to implement similar deterrent policies regardless of whether they expect to share liability with their agents. The most severe employer repercussions, discharge and demotion, are fairly inexpensive, ${ }^{71}$ and the need to maintain a good reputation in the public eye hopefully provides most employers with enough incentive to deter their agents from discriminating, regardless of the potential for legal liability. Because agent liability adds the deterrent of personal bankruptcy without detracting significantly from deterrence by employers, ${ }^{72}$ common sense indicates that agent liability under Title VII increases overall deterrence for discriminating.

\section{Agent Liability Increases Overall Deterrence by Increasing the}

Incidence of Lawsuits, the Resulting Damage Awards, and Undesirable Risk to Potential Defendants

In addition to creating direct exposure to liability for agents, agent liability creates at least three additional avenues of deterrence. First, as explained in the previous section, victims are more likely to sue if agent liability is recognized. ${ }^{73}$ The added incentive for victims to litigate creates additional incentives for agents not to discriminate, because they will more likely be held accountable for their actions. Second, agent liability often affects the magnitude of the damage award accompanying a finding of unlawful discrimination. ${ }^{74}$ Although the victim's injuries alone determine the compensatory damage award, ${ }^{75}$ punitive damages are calculated by determining the appropriate punishment on a per-defendant basis. ${ }^{76}$

7 Discharge and demotion do involve the expense of replacing the employee and any expenses that might accompany a potential lawsuit by the employee against whom repercussions are directed.

72 Although agents are not deterred directly unless they are aware of what conduct exposes them to liability, employers have strong incentives to educate their agents about the law so long as vicarious liability is available to plaintiffs.

73 See supra part II.A.

${ }^{74}$ Agent liability does not affect the probability of a plaintiff's success. See Carrillo, supra note 6, at 91 (arguing that the accuracy of determining unlawful discrimination at trial is unaffected by changes in who may be held liable for Title VII violations).

${ }^{75}$ See RESTATEMENT (SECOND) OF TORTS, supra note 62, $\$ 902$ (discussing compensatory damages).

${ }^{76}$ See Rodgers v. Fisher Body Div., Gen. Motors Corp., 739 F.2d 1102, 1109 (6th Cir. 1984) (citing deterrence as the purpose of punitive damages under Title VII), cert. denied, 470 U.S. 1054 (1985); Ayers v. Christiansen, 564 P.2d 458, 461 (Kan. 1977) (measuring punitive damages by the "extent and enormity of the wrong, the intent of the party committing it, and generally, all circumstances attending the particular 
Because punitive damages can be awarded against each liable defendant, ${ }^{77}$ damage awards for Title VII generally increase as additional defendants are found culpable. By thus increasing the aggregate penalty for discriminating that is borne by liable defendants, agent liability probably increases overall deterrence. Third, agent liability introduces another risk to potential defendants because defendants would be unable to predict with certainty the fraction of the damage award they would pay if a Title VII violation is proven. ${ }^{78}$ Because potential defendants generally are risk averse, ${ }^{79}$ the increased risk associated with agent liability also suggests that agent liability furthers Congress's goal of deterring employment discrimination. ${ }^{80}$

\section{Agent Liability Is Good Public Policy}

Public policy considerations, like analyses of legislative history, frequently resolve statutory ambiguities. ${ }^{81}$ Part II of this Comment considered the policy reasons leading to Title VII's enactment and concluded that agent liability under Title VII not only helps compensate victims of employment discrimination, but also probably deters discriminatory conduct. This Part continues the public policy analysis, first by showing that agent liability comports with firmly established common-law principles, and then by explaining why the major policy-based objections to agent liability are unpersuasive. ${ }^{82}$

transaction"); see also RESTATEMENT (SECOND) OF TORTS, supra note $62, \S 908$ (discussing punitive damages).

77 See RESTATEMENT (SECOND) OF TORTS, supra note 62, \$ 909 ("Punitive damages can properly be awarded against [an employer] because of an act by an agent . . ..").

${ }^{78}$ As used in this context, the economic concept of risk means, in essence, uncertainty. Absent agent liability, employers always are responsible for paying the entire damage award, so no risk exists regarding the fraction of the damage award paid by each defendant. See RICHARD A. POSNER, ECONOMIC ANALYSIS OF LAW § 1.2, at 12 (4th ed. 1992) (comparing the concept of risk to utility and stating that both include uncertainty as a component).

79 See A. Mitchell POLINSKY, AN InTROduction to LAw AND ECONOMics 53 (1989) (stating that it is generally realistic to assume that parties are risk averse); POSNER, supra note $79, \S 1.2$, at 12 (noting that economic theory holds that "most people are risk averse most of the time ${ }^{n}$ ); Sykes, supra note 67, at 595 (same).

${ }^{80}$ Although insurance reduces or eliminates risk, courts might be unwilling to permit insurance in the context of employment discrimination. See, e.g., Kyriazi v. Western Elec. Co., 476 F. Supp. 335, 340 (D.N.J. 1979) (forbidding employer from compensating agents for tort liability of sexual harassment).

${ }^{81}$ See $2 B$ SINGER, supra note $19, \S 56.01$ ("Public policy considerations exert a significant influence in the process of statutory interpretation by the courts.").

${ }^{82}$ Often, courts also look to the other major federal statutes combatting 


\section{A. Common-Law Principles Require Personal Accountability}

Courts have long appreciated the prominent role of the common law in answering questions of public policy. ${ }^{83}$ In the Title VII context, the Supreme Court explicitly has recognized the importance and general applicability of common-law agency principles. ${ }^{84}$ For a multitude of reasons, the common law supports agent liability.

employment discrimination, such as the Age Discrimination in Employment Act (ADEA), 29 U.S.C. $\$ \S 621-634$ (1988 \& Supp. V 1993), and the Americans with Disabilities Act (ADA), 42 U.S.C. $\$ \S 12,101-12,213$ (Supp.V 1993), for their potential usefulness as a source of analogy for interpreting Title VII. See, e.g., Vakharia v. Swedish Covenant Hosp., 824 F. Supp. 769, 785-86 (N.D. Ill. 1993) (treating the liability schemes of Title VII and the ADEA identically); see also 2B SINGER, supra note $19, \S 51.01$ ("Other statutes dealing with the same subject as the one being construed ... [comprise] another form of extrinsic aid useful in deciding questions of interpretation."). Interpretations of agent liability under the two other major employment discrimination statutes, however, are not particularly helpful, because courts usually look to Title VII as a guide when determining agent liability under these two statutes. See, e.g., Coffin v. South Carolina Dep't of Social Servs., 562 F. Supp. 579, 589 (D.S.C. 1983) (using Title VII interpretation in deciding agent liability under the ADEA). To look at these decisions for guidance would therefore be circuitous. Those courts that have looked outside the Title VII framework, however, have not reasoned persuasively. For example, one federal district court determining whether agent liability is available under the ADEA partially relied upon case law holding agents liable under the Fair Labor Standards Act, 29 U.S.C. \$§ 201-219 (1988). See Wanamaker v. Columbian Rope Co., 740 F. Supp. 127, 134-35 (N.D.N.Y. 1990). This reliance was misplaced, however, because agent liability was not clearly recognized under the Fair Labor Standards Act at the time the ADEA was enacted. See House v. Cannon Mills Co., 713 F. Supp. 159, 160 (M.D.N.C. 1988). Another court decided that agent liability should be denied under the ADEA because Congress had amended the National Labor Relations Act, 29 U.S.C. $\$ \S 141-169$ (1988), to include the term "agent" as a means of limiting employer liability. See Friend v. Union Dime Sav. Bank, 24 Fair Empl. Prac. Cas. (BNA) 1307, 1310 (S.D.N.Y. 1980). Such reasoning, however, is inherently flawed because Congress's intention to limit employer liability has no apparent bearing on its intentions regarding agent liability. Courts have seldom considered the issue of agent liability under the ADA, making guidance from its interpretation undependable at best. See John P. Furfaro \& Maury B. Josephson, Liability of Supervisors, N.Y. L.J., Sept: 3, 1993, at 3, 27 ("Since the passage of the ADA, there has been little litigation [on the issue of agent liability] under it."). But see EEOC v. AIC Sec. Investigations, Ltd., 823 F. Supp. 571, 581 (N.D. Ill. 1993) (upholding liability against an agent under the ADA).

${ }^{83}$ See 2B SINGER, supra note 19, $\$ 56.03$ ("[C]ommon law . . . constitutes a fertile source from which to determine public policy."); see also id. $\$ 55.01$ (stating that looking to the common law for guidance is a "time-honored method for solving new problems in [statutory] law").

${ }^{84}$ See Meritor Sav. Bank v. Vinson, 477 U.S. 57, 72 (1986) (focusing on Congress's inclusion of "agent" in Title VII's definition of "employer"). The Meritor Court implicitly treated Title VII violations as the functional equivalent of torts by citing to sections of the Restatement (Second) of Agency that deal with employer liability for torts committed by agents. See id.; see also RESTATEMENT (SECOND) OF AGENCY, supra note $3, \S \S 219-237$ (defining the employer-employee relationship). 
The Restatement (Second) of Agency contains the strongest common-law endorsement of agent liability. ${ }^{85}$ It remarks that, regardless of whether vicarious liability is available, "[an] agent who does an act otherwise a tort is not relieved from liability by the fact that he [or she] acted at the command of the principal or on account of the principal. ${ }^{n 66}$ This provision firmly embodies the notion of personal accountability under the law. Applied to Title VII's liability scheme, this provision strongly supports agent liability.

Agent liability under Title VII is further supported by the two common-law tort liability theories identified by Oliver Wendell Holmes. ${ }^{87}$ Under one theory, tort liability is "a penalty for disobedience ... that ... ought only to be based upon personal fault." ${ }^{88}$ This theory, therefore, requires liability of agents who discriminate. ${ }^{89}$ The other theory identified by Holmes states that liability should fall on the most blameworthy party. ${ }^{90}$ In the context of employment discrimination, agents who discriminate are usually deemed more blameworthy than their employers, who are merely vicariously exposed to liability for the violations of their agents. ${ }^{91}$ As such, recognizing employer liability without recognizing agent liability would be anomalous as a legal doctrine. Regardless of how the relative blame is distributed between the agent and the employer, however, the agent is still more blameworthy than the victim for the injury inflicted. As such, the blameworthiness theory of tort liability also requires that victims be allowed to sue agents who discriminate.

${ }^{85}$ The Supreme Court specifically has directed lower courts to the Restatement (Second) of Agency when assessing employer liability in cases of hostile environment sexual harassment. See Meritor, 477 U.S. at 72.

${ }^{86}$ RESTATEMENT (SECOND) OF ACENCY, supra note $3, \S 343$ (emphasis added). Although three exceptions to this general rule exist, none of the exceptions is applicable to agent liability under Title VII. See id. (delineating exceptions to the general rule of agent liability).

${ }^{87}$ Holmes specifically considered justifications for imposing liability for unintentional harms. See HOLMES, supra note 1, at 81-82. A fortiori, these justifications also apply to intentional harms, for which an even lesser justification would permit imposing liability on the tortfeasor.

${ }^{83} \mathrm{Id}$. at 82 (emphasis added).

${ }^{89}$ Courts implicitly recognize the highly personal nature of discrimination by agents. See, e.g., DeWald v. Amsterdam Hous. Auth., 823 F. Supp. 94, 103 (N.D.N.Y. 1993) (holding, in the sexual harassment context, that agents are only susceptible to suit if acting independently and not as surrogates for employers).

${ }^{90}$ See HOLMES, supra note 1 , at 82.

${ }^{91}$ But see supra part II.A.1 (discussing the potential unavailability of vicarious liability for hostile environment sexual harassment). 
Finally, the common law generally permits employers that incur vicarious liability to seek full indemnification from their agents. ${ }^{92}$ This allowance clearly suggests that the common law required culpable agents, when feasible, ultimately to compensate victims for the damages resulting from discrimination. This result is possible only if agent liability is recognized, because parties can seek indemnification only from those who could have been sued in the first instance. ${ }^{93}$ Thus, all things considered, the common law strongly rejects a liability scheme in which employers incur vicarious liability; yet discriminating agents are not held accountable to their victims.

\section{B. Policy Objections to Agent Liability Are Unpersuasive}

Critics of agent liability under Title VII have advanced several policy arguments suggesting its undesirability. One argument proposes that agent liability has a "chilling effect" on employees that encourages them to limit interactions so as to avoid exposure to liability, thereby interfering with the efficient operation of businesses. ${ }^{94}$ Whether agent liability in fact creates a "chilling effect" is ambiguous, however, because of agent liability's competing effects on direct deterrence and employer deterrence, ${ }^{95}$ and because employees do not necessarily fear lawsuits as much as they fear that initiating lawsuits will lead to employer repercussions. ${ }^{96}$ Ironically, if employees do have a greater fear of legal liability, as this argument maintains, agent liability accordingly furthers the congressional goal of deterrence. ${ }^{97}$ The "chilling effect" argument, therefore,

92 See KeETON ET AL., supra note 27, § 51, at 341; see also RESTATEMENT (SECOND) OF TORTS, supra note $62, \S 886 \mathrm{~B}(2)$ (a) (stating that indemnity may be granted in cases in which the indemnitee is only vicariously liable for the conduct of the indemnitor).

${ }^{93}$ See RESTATEMENT (SECOND) OF TORTS, supra note $62, \S 886 \mathrm{~B}(1)$.

${ }^{94}$ See, e.g., Bramesco v. Drug Computer Consultants, 834 F. Supp. 120, 123 (S.D.N.Y. 1993) ("[E]xposure of [agents] to personal liability may interfere with the functions of their employers . . . "); Archer v. Globe Motorists Supply Co., 833 F. Supp. 211, 214 (S.D.N.Y. 1993) ("Congress in the public sector context has recognized that liability of individual personnel for acts attributable to an institutional entity can have an undesirably chilling effect on the ability of the entity to perform its functions." (citing legislative history of 28 U.S.C. $\$ 2679$ (b) (1988))).

${ }^{95}$ Employers also decrease their exposure to Title VII liability if interactions among coworkers are limited. See Conway, supra note 54, at 1177 (arguing that vicarious liability creates employer incentives to "establish rigid policies either severely limiting social encounters between supervisors and subordinates or prohibiting them altogether"); $c f$. supra part II.B (discussing the deterrent effect of agent liability).

${ }^{96}$ See supra notes $67-68$ and accompanying text.

${ }^{97}$ See supra note 6 (stating that one purpose of Title VII is to eliminate employment discrimination); see also supra part II.B. 
ultimately defeats itself, because in statutory construction public policy considerations play a secondary role to legislative intent. ${ }^{98}$

Another argument maintains that agent liability under Title VII is superfluous ${ }^{99}$ because it accomplishes nothing more than increasing the expense of litigation. ${ }^{100}$ For victims of discrimination, however, suing agents is often necessary in cases involving bankrupt employers and in cases of hostile environment sexual harassment. ${ }^{101}$ Furthermore, this argument apparently overlooks the important nonmonetary benefits associated with bringing the actual perpetrator into court. ${ }^{102}$ The frequency with which victims of discrimination voluntarily incur the extra cost of suing agents in addition to the employer bespeaks the significance of this oversight. ${ }^{103}$

A third argument is that agent liability under Title VII is economically inefficient. ${ }^{104}$ This argument first presupposes the existence of an optimal level of deterrence and then attempts to gauge whether agent liability produces the optimal result. ${ }^{105}$ Such an approach, however, is repugnant to Congress's objective of eliminating employment discrimination altogether. ${ }^{106}$ Efficiency arguments, therefore, do not pose a valid objection to agent liability under Title VII. ${ }^{107}$

${ }^{98}$ See 2B SINGER, supra note $19, \S 56.01$ (discussing the role of public policy in statutory interpretation).

${ }^{99}$ See, e.g., Bramesco v. Drug Computer Consultants, 834 F. Supp. 120, 123 (S.D.N.Y. 1993) ("[P]laintiff gains nothing [by suing agents under Title VII] apart from consumption of time and creation of bitterness ...." ).

${ }^{100} C f$., e.g., Sykes, supra note 67 , at $570-71 \mathrm{n} .19$ ("Also, vicarious liability adds an additional party to litigation and thus may increase litigation costs significantly.").

${ }^{101}$ See supra parts II.A.1-2 (discussing problems of bankrupt employers and problems related to hostile environment sexual harassment).

${ }^{102}$ See, e.g., Meritor Sav. Bank v. Vinson, 477 U.S. 57, 77 (1986) (Marshall, J., concurring) (identifying situations in which the victim of discrimination "seeks not money damages but injunctive relief").

${ }^{103}$ That victims of discrimination often sue agents in addition to the employer may alternatively signal that victims of discrimination commonly doubt the financial stability of employers. See supra part II.A.2. This interpretation would also undercut arguments claiming redundancy in suing both employers and agents.

${ }^{104}$ Cf. Sykes, supra note 67, at 567 (arguing that employers in competitive markets who are not vicariously liable for the torts of their agents will produce beyond the socially optimal level).

${ }^{105}$ See id.

${ }^{106}$ See supra note 6 and accompanying text (stating that one purpose of Title VII is to eliminate employment discrimination).

${ }^{107}$ See 2B SINGER, supra note $19, \S 56.01$ (discussing the role of public policy in statutory interpretation). Economic efficiency arguments against agent liability, even if legitimately considered, probably should be rejected for another reason: "[E]ven 
A final policy argument, not economically based, states that agent liability under Title VII can result in injustice when the employer is primarily to blame for the discrimination at issue. ${ }^{108}$ In such cases, however, the general rule of indemnification does not apply, because both the employer and the agent have directly violated Title VII. ${ }^{109}$ In these situations a rule of contribution applies instead, whereby damages are equitably divided between the employer and its agents. ${ }^{110}$ Therefore, when fairness dictates, damages will fall primarily or entirely on the employer. ${ }^{111}$ Furthermore, in the unlikely event that only agents are sued, ${ }^{112}$ they could simply join their employers as defendants. ${ }^{113}$ This argu-

[when] the [employer] is strictly liable, the employee's level of care will be inadequate" unless employees are directly exposed to statutory sanctions. A. Mitchell Polinsky \& Steven Shavell, Should Employees Be Subject to Fines and Imprisonment Given the Existence of Corporate Liability, 13 INT'L REv. L. \& ECON. 239, 239-40 (1993). Polinsky and Shavell base this conclusion on their assertion that employers have "limited ability to discipline [their employees]: the effect of dismissal is limited by the presence of alternate opportunities for employees." Id.

108 The employer is likely to be primarily to blame for the discrimination when it directs its agents to act in a discriminatory manner. Courts currently appear unwilling to permit agent liability in these situations. See, e.g., Bramesco v. Drug Computer Consultants, 834 F. Supp. 120, 123 (S.D.N.Y. 1993) (holding that agents cannot be liable for Title VII violations "absent separate intentional misconduct") (citing Miller v. Maxwell's Int'l Inc., 991 F.2d 583 (9th Cir. 1993), cert. denied, 114 S. Ct. 1049 (1994)); Vakharia v. Swedish Covenant Hosp., 824 F. Supp. 769, 784 (N.D. III. 1993) (holding that agents may be liable for Title VII violations not committed under direction from their superiors); Archer v. Globe Motorists Supply Co., 833 F. Supp. 211, 214 (S.D.N.Y. 1993) (holding that agents may be liable for "individualized personal misconduct" separate from mandatory institutionalized policy); Bradley v. Consolidated Edison Co., 657 F. Supp. 197, 207 (S.D.N.Y. 1987) (holding that agents cannot be liable under Title VII for following employer policy); see also Bridges v. Eastman Kodak Co., 800 F. Supp. 1172, 1180 n.9 (S.D.N.Y. 1992) ("[T] he normal rule [is] that [agent] liability must be premised on individual acts distinct from the organization's policy." (citing Kentucky v. Graham, 473 U.S. 159, 166 (1985))).

${ }^{109}$ See RESTATEMENT (SECOND) OF TORTS, supra note $62, \S 886 \mathrm{~B}$ (delineating the general rules of indemnification).

${ }^{110}$ See id. $\$ 886 \mathrm{~A}$ (outlining the general rules of contribution among joint tortfeasors).

${ }^{111}$ The commentary to the Restatement (Second) of Torts recognizes that "a growing number of states . . . base[] [contribution] according to the comparative fault of the tortfeasors" instead of equally dividing damages. Id. $\$ 886 \mathrm{~A}$, cmt. h; see also id. $\S 886 \mathrm{~A}(2)$ ("No tortfeasor can be required to make contribution beyond his own equitable share of the liability."); supra note 110 (citing cases in which courts have distributed liability according to perceived fault).

${ }^{112}$ See 5 FOWLER V. HARPER ET AL., THE LAW OF TORTS $\$ 26.1$, at 5 (2d ed. 1986) (stating that when both employers and agents are potentially liable for torts, plaintiffs only sue employers "in the vast majority of cases").

113 See Barbara L. Schlei \& PaUl Grossman, Employment Discrimination Law 1109-10 (2d ed. 1983) (discussing the joinder of one defendant by another). In 
ment, then, is no more convincing than the economically based arguments opposing agent liability.

\section{CONCLUSION}

The majority of federal courts that have squarely addressed the issue of agent liability have chosen to insulate discriminating agents from suit, ${ }^{114}$ thereby systematically favoring powerful company executives $^{115}$ over their usually less wealthy subordinates. This result not only contravenes the American common-law tradition and basic principles of justice, but also hinges upon improper methods of statutory construction. A literal reading of Title VII provides a sound basis for agent liability, and the congressional objectives of compensation and deterrence require that agents be held accountable for their discrimination. Agent liability affirmatively encourages victims to enforce their rights and also provides the only means of redress in situations in which employers are bankrupt and in many instances of hostile environment discrimination. Furthermore, although it cannot be stated conclusively, agent liability probably increases deterrence under Title VII. Public policy objections to agent liability seem largely unfounded, especially considering the well-established rule that a remedial statute should be liberally construed so as to effectuate its purposes. ${ }^{116}$ When

addition, Rule 20 of the Federal Rules of Civil Procedure provides:

All persons ... may be joined in one action as defendants if there is asserted against them jointly, severally, or in the alternative, any right to relief in respect of or arising out of the same ... occurrence, or series of ... occurrences and if any question of law or fact common to all defendants will arise in the action.

FED. R. CIV. P. 20.

${ }^{114}$ See supra notes 15-16 (cataloguing rulings on agent liability from federal courts of appeals and district courts).

${ }^{115}$ All Title VII agents are "powerful" in the sense that they must exert significant control over decision-making processes in order to be considered agents within the meaning of the statute. See supra note 12 (discussing the definition of "agent" under Title VII).

${ }^{116}$ Many court decisions state that Title VII ought to be construed liberally so as to further Congress's purpose for enacting the legislation. See, e.g., Hamilton v. Rodgers, 791 F.2d 439, 442 (5th Cir. 1986) ("Title VII 'should be accorded a liberal interpretation in order to effectuate the purpose of Congress to eliminate the inconvenience, unfairness, and humiliation of ethnic discrimination.") (quoting Rogers v. EEOC, 454 F.2d 234, 238 (5th Cir. 1971), cert. denied, 406 U.S. 957 (1972)); Owens v. Rush, 636 F.2d 283, 287 (10th Cir. 1980) (construing liberally the term "employer" (citing Baker v. Stuart Broadcasting Co., 560 F.2d 389, 391 (8th Cir. 1977))); see also 3 SINGER, supra note 19, $\$ 60.01$, at 147 ("Remedial statutes are liberally construed to suppress the evil and advance the remedy." (footnote omitted)); 
construed properly, Title VII produces the just result: the perpetrators of discrimination suffer rather than their victims. Title VII reveals that Congress desired the statute to be broadly construed, in order to eliminate sex based discrimination in employment." (citation omitted)). 